\title{
Phytochemical Screening and Biological Activity Studies of the Extract from the Bark of Ricinodendron heudoletti, Euphorbiaceae
}

\author{
Oyono Victor ${ }^{1}$, Fokunang Charles ${ }^{1,4}$, *, Tembe-Fokunang Estella ${ }^{1}$, Tsague Marthe ${ }^{1}$, \\ Messi Angélique ${ }^{2}$, Assam Jean ${ }^{3}$, Ngameni Bethelemy ${ }^{1}$, Kechia Frederick ${ }^{1,4}$, \\ Armel Herve Nwabo Kamdje ${ }^{5}$, Penlap Veronique ${ }^{2}$, Ngadjui Bonaventure ${ }^{1}$ \\ ${ }^{1}$ Department of Pharmaceutical Sciences and Traditional Pharmacopeia, Faculty of Medicine and Biomedical Sciences, University of \\ Yaounde 1, Yaounde, Cameroon \\ ${ }^{2}$ Department of Biochemistry, Faculty of Sciences, University of Yaounde 1, Yaounde, Yaounde, Cameroon \\ ${ }^{3}$ Department of Biochemistry, Faculty of Sciences, University of Douala, Douala, Cameroon \\ ${ }^{4}$ Department of Biological Sciences, Faculty of Sciences, the University of Bamenda, Bamenda, Cameroon \\ ${ }^{5}$ Department of Biological Sciences, University of Ngaoundere, Ngaoundere, Cameroon
}

Email address:

charlesfokunang@yahoo.co.uk (F. Charles)

${ }^{*}$ Corresponding author

\section{To cite this article:}

Oyono Victor, Fokunang Charles, Tembe-Fokunang Estella, Tsague Marthe, Messi Angélique, Assam Jean, Ngameni Bethelemy, Kechia Frederick, Armel Herve Nwabo Kamdje, Penlap Veronique, Ngadjui Bonaventure. Phytochemical Screening and Biological Activity Studies of the Extract from the Bark of Ricinodendron heudoletti, Euphorbiaceae. Journal of Diseases and Medicinal Plants.

Vol. 2, No. 6, 2016, pp. 83-89. doi: 10.11648/j.jdmp.20160206.14

Received: July 6, 2016; Accepted: July 12, 2016; Published: January 10, 2017

\begin{abstract}
The fractions and pure compounds isolated from the bark of $R$. heudoletti were tested for their antibacterial properties on negative and positive gram bacteria using the disc diffusion method. Phytochemical analysis of the fractions and pure compound isolated was also conducted. The inhibitions parameters of the fractions and pure compound were determined using macro dilution method. The results showed that fraction and isoflavonoid exhibited a significant antibacterial effect against twelve strains isolated from patients. These micro-organisms were Gram-negative (Escherichia coli, Salmonella typhi, Shigella flexneri, Pseudomonas aeroginosa, Enterobacter cloacae, Klebsiella pneumoniae, Klebsiella oxytoca, Morganella morganii, Citrobacter freundi, and Proteus vulgaris) and positive gram (Staphylococcus aureus, and Streptococcus feacalis). The ratio of minimal bactericidal concentration (MBC) over the minimal inhibitory concentration (MIC) indicated a promising bactericidal effect of fractions and pure compounds isolated. These results support the current common use of the bark of Ricinodendron heudoletti and flavonoids in the treatment of some infectious diseases.
\end{abstract}

Keywords: Biochemistry Properties, Flavonoids, Infectious Diseases, Ricinodendron heudoletti

\section{Introduction}

Medicinal plants constitute an important aspect of study for the development of phytomedicine. Studies on traditional medicine has become an important priority of the World health organization since almost $80 \%$ of the population in developing economies use medicinal plants as alternative source of treatment of diseases [1, 2]. The search for new chemical entities from herbal materials has increase the interest of Cameroonian scientist to exploit the rich cocktail of plant biodiversity for phytochemical screening of potential compounds of pharmaceutical importance and test of activities [3, 4]. The current problem of bacterial resistance and nosocomial infection has led to more research on the use of medicinal plant research for potential new drugs in the drug development pipeline. [1,5]. The bark extract of $R$. heudoletti is used against cough, as poison antidote and for the treatment of intestinal diseases. The bark is also used to 
treat yellow fever, malaria, headache, stomach pains and in some cases it can help pregnant women [6]. Infusion of barks of $R$. heudelotii has been shown to possess diuretic and aphrodisiac effects. The leaves are used to treat dysentery and the fruits can be used as spices $[6,7]$. $R$. heudelotii is widely used for the above mentioned biological activities; no toxicological study of the plant has been reported previously as well as its in vitro antibacterial and antioxidant activities in Cameroon [8]. As a contribution to the search for nontoxic, novel antibacterial properties from medicinal plants of Cameroon.

\section{Materials and Methods}

\subsection{Plant Material}

The bark of $R$. heudoletti was collected at Minlamizibi in the South Region of Cameroun in January, 2009. The biological identification of the plant was done by the national herbarium in Yaoundé where the voucher identification was assigned under the reference number 16610/SFR/CAM

\subsection{Chemicals}

The antibiotics gentamicin was purchased from local community pharmacy. Methanol ethanol, ethyl acetate, hexane chloroform, nutrient agar and nutrient broth were purchased from Merck Company and the other chemicals used were from Sigma Company

\subsection{Antibacterial Assay Microorganisms}

Twelve bacterial strains isolated from patients at the "Centre Pasteur of Cameroon", a reference center for disease diagnostic and identification were used for the evaluation of antibacterial activity. These micro-organisms were Gramnegative (Escherichia coli, Salmonella typhi, Shigella flexneri, Pseudomonas aeroginosa, Enterobacter cloacae, Klebsiella pneumoniae, Klebsiella oxytoca, Morganella morganii, Citrobacter freundi, and Proteus vulgaris) and positive gram (Staphylococcus aureus, and Streptococcus feacalis).

\subsection{Inocula Preparation}

An inoculum for each micro-organism was prepared from broth cultures containing approximately $5.10^{5}$ to $9.10^{6}$ colony forming units per mililiter (CFU/ml). Each diluted into (1:50) inoculum, was applied as a lawn with a micropipette calibrated to deliver $50 \mu \mathrm{l}$ containing around $9.10^{6} \mathrm{CFU}$ [9]. The discs impregnated with extract and pure methanol only to show if there was any activity using pure methanol solvent, were evaporated for 24 hours at sterile condition. The inoculated plates were incubated at $37^{\circ} \mathrm{C}$ for $24 \mathrm{~h}$. Each assay in this experiment was repeated 3 times.

\subsection{Determination of the Diameters of Inhibition Zone}

The extracts were tested in vitro for antibacterial activity by the standard disc diffusion method against the microorganisms at a concentration of $80 \mathrm{mg} / \mathrm{ml}$ with pure methanol. Gentamycin used as standard antibiotic (positive control) was tested at a concentration of $1 \mu \mathrm{g} / \mu \mathrm{l}$. The diameters of inhibition zones produced by these extracts and disc impregnated with pure methanol were then compared to standard antibiotic (Gentamycin).

\subsection{Minimum Inhibitory Concentration (MIC) Determination}

For MICs determination, only the most sensitive microorganisms were tested with the extract. Serial dilutions were from $75,93 \mu \mathrm{g} / \mathrm{ml}$ to $3000 \mu \mathrm{g} / \mathrm{ml}$ of extract in the nutrient broth medium. $100 \mu \mathrm{l}$ of the suspension of each pathogenic bacterium $\left(10^{6}\right.$ cells $\left./ \mathrm{ml}\right)$ were added and incubated at $37^{\circ} \mathrm{C}$ for $24 \mathrm{~h}$. Standard antibiotic (positive control) was tested in the concentration between 2.5 to 80 $\mu \mathrm{g} / \mathrm{ml}$. The lowest concentration which did not show any macroscopic growth of tested microorganism was identified as the MIC.

\subsection{Minimum Bactericidal Concentration (MBC) Determination}

For MBC determination, $100 \mu \mathrm{l}$ of each tube of bacterial strain was subculture in the nutrient broth medium at $37^{\circ} \mathrm{C}$ for $24 \mathrm{~h}$. The absence of any macroscopic growth of the nearest MIC tube was identified as the MBC [9].

\subsection{Phytochemical Analysis}

Phytochemical tests were carried out as described by Odebiyi and Sofowara [10]. The phytochemical analyzes were performed, focusing on the color reaction and precipitate. The phytochemical screening has been summarized in table $1 \mathrm{~A}$ and $1 \mathrm{~B}$.

Table 1a. Phytochemical Screening of the hydroalcoholic extract and its fractions [11, 12, 13].

\begin{tabular}{lll}
\hline Métabolite & Reagent Methods & Indicator \\
\hline Polyphenols & Ferric chloride & Greenish color. \\
& Lead acetate & Whitish precipitate \\
Flavonoids & Iso amyl alcohol/Magnesium & Pink color or red color \\
& + hydrochloric acid & Reddish precipitate \\
Alkaloids & Hodger & Whitish precipitate \\
& Wagner & Whitish-yellow creamy precipitate \\
Cardiac glycosides & Mayer & Green-blue color \\
& Glacial acetic acid/ Ferric chloride & Persistent frothing \\
\hline
\end{tabular}




\begin{tabular}{lll}
\hline Métabolite & Reagent Methods & Indicator \\
\hline Tannins & Ferric chloride & Green, blue or black color \\
Anthocyanins & Sulfuric acid/Ammonia & Purple-blue \\
Quinones & Sodium hydroxyde & Red or purpe color \\
Mucilages & Ethanol $95^{\circ}$ & Air bubbles \\
Resins & Glacial acetic acid/ Sulfuric acid & Yellow color \\
Betalains & Sodium hydroxyde & Yellow color \\
Terpenoids and steroids & Liebermann-Burchard & Pink, blue or grey color \\
Coumarins & Ferric chloride/nitric acid & Green or blue color \\
Oxalates & Glacial acetic acid & Black or green color \\
\hline
\end{tabular}

\subsection{Extraction and Purification}

The bark of R. heudoletti was air dried and pulverized. The resulting powder $(5 \mathrm{~kg})$ was macerated in methanol for 72 hours; the concentrated methanolic extract was treated with hydrochloric acid $(5 \%)$. The aqueous solution was made alkaline with ammonia and extracted with acetate. The methanolic extract was screened for antibacterial activity. The active fractions were subjected to a bio-guided fractionation by flash chromatography on silica column. Gradient elution using hexane- ethyl acetate (Hex-AE). The active fractions F1 $(6.05 \mathrm{~g})$ obtained with methanol-ethyl acetate (Me-EA) (20\%) was purified by sephadex chromatography gradient eluted with hexane ethyl acetate to afford 14 fractions (FA1-FA14). The active fraction FA1 and FA10 was crystallized from acetone to yield $422 \mathrm{mg}$ of shiny yellow crystals and $300 \mathrm{mg}$ of shiny white crystals. Those $422 \mathrm{mg}$ yellow crystals were identified as flavonoids (Iso flavonoids) on the basis of spectrophotometric data

\section{Results and Discussions}

\subsection{Phytochemical Screening}

The results of phytochemical screening as shown in table 1 , showed the presence of alkaloids, poly phenol, flavonoids, saponins, cardiac glycoside, triterpenes. The poly phenols group constitutes the principal component of $R$. heudoletti extract with three bioactive subgroup: tannins flavonoids and saponins. Alkaloids and steroids whose anti micro bacterial activities have been demonstrated were also found in this extract. Earlier studies have associated high accumulation of alcaloids [2], flavonoids [14], cardiac glycoside and saponins $[3,17]$, all linked to promising antibacterial and antioxidant activities in studied medicinal plants.

Table 1b. Phytochemical screening of $R$. heudoletti extract.

\begin{tabular}{lclll}
\hline Components & Hexane extract & Ethyl acetate Extract & Ethanolic Extract of. \\
\hline Phenol & + & + & Methanol Extract & - \\
Polyphenol & + & + & ++ & + \\
Flavonoids & - & + & + & + \\
Saponins & - & + & + & + \\
Cardiac Glycosides & - & + & + & + \\
Triterpens & - & + & + & ++ \\
alkaloids & + & + & + & + \\
\hline
\end{tabular}

$(+)$ Presence of component; (++) Abundance of component; (-) Absence of component

The results of thin layer chromatography table 2 showed that methanol and ethyl acetate $10 \%$ were the best eluted system that separated the compound for the crude extract of $R$. heudoletti and that explicate the differential solubility of phenolics component in the high polar system. This result was collaborated the work of [1] methanol and ethyl acetate were good solvent of elution of plant extracts separation

Table 2. Chromatogram of the methanol extract from $R$. heudoletti.

\begin{tabular}{|c|c|c|c|c|c|}
\hline $\begin{array}{l}\text { Chromatogram of the } \\
\text { methanol's extract }\end{array}$ & $S_{1}:$ Hex-AE $10 \%$ & $\mathrm{~S}_{2}:$ Hex-AE $40 \%$ & $\mathrm{~S}_{3}$ : AE pur & $\mathrm{S}_{4}:$ AE-MeOH 5\% & $\mathrm{S}_{5}: \mathrm{AE}-\mathrm{MeOH} 10 \%$ \\
\hline UV: $365 \mathrm{~nm}$ & 1 blue stain & $\begin{array}{l}-1 \text { blue fluorescent strain } \\
-1 \text { green stain }\end{array}$ & $\begin{array}{l}-1 \text { green stain } \\
-1 \text { blue and fluorescent } \\
\text { strain } \\
-1 \text { green strain }\end{array}$ & $\begin{array}{l}-1 \text { violet strain } \\
-2 \text { green and clear strains } \\
-1 \text { bleu fluorescent strain } \\
-1 \text { green strain }\end{array}$ & $\begin{array}{l}-1 \text { violet strain } \\
-2 \text { green and clear strains } \\
-1 \text { blue fluorescent strain } \\
-1 \text { green strain }\end{array}$ \\
\hline UV: $254 \mathrm{~nm}$ & 1 stain & 2 blue and dark stains & 2 blue and dark stains & 4 Blue and dark stains & 4 blue and dark stains \\
\hline $\begin{array}{l}\text { After pulverization at } \\
\mathrm{H}_{2} \mathrm{SO}_{4} 50 \%, \Delta=105^{\circ} \mathrm{C}\end{array}$ & No migration & Two stains & 3 stains & 5 stains & 5 stains \\
\hline
\end{tabular}

The methanol acetate ethyl system ( 5 and $10 \%$ ) fraction of the methanolic extract of $R$. heudoletti released 5 components coloured in green clear, blue fluorescent violet. These characteristics indicated the presence of flavonons, flavons flavonols and glycosids [15].

The results of flash chromatography showed the fractions from methanolic $100 \%$ elution given $0.84 \mathrm{~g}$. The methanolethyl acetate system $(10,20,30,50 \%)$ produced fractions 
weight of $7 \mathrm{~g}$.

Table 3. Sephadex chromatography of plant extract fractions.

\begin{tabular}{lll}
\hline Elution solution & Fractions & Observations and results \\
\hline & $1-6$ & Oily product \\
& $7-20$ & flow \\
& $21-26$ & Flow and stain \\
Hex-EA 50\% & $27-34$ & flow \\
& $35-44$ & Flow and stain \\
& $45-74$ & flow \\
& $75-82$ & flow \\
Hex-EA 60\% & $83-99$ & nothing \\
& $100-109$ & nothing \\
& $110-111$ & Nothing \\
Pure ethyl acetate & $112-113$ & flow \\
& $114-115$ & Flow and strain \\
& $116-122$ & Flow and strain \\
& $123-137$ & nothing \\
AE-MeOH 5\% & $138-147$ & flow \\
& $148-150$ & Nothing \\
& $151-160$ & Yellow shiny crystals \\
& $161-176$ & Yellow shiny crystals \\
AE-MeOH 10\% & $177-200$ & Yellow shiny crystals \\
& $201-210$ & Yellow shiny crystals \\
& $211-234$ & Yellow crystals \\
AE-MeOH 15\% & 235 & White crystal \\
& $236-244$ & White crystal \\
AE-MeOH 20\% & $245-254$ & White crystal \\
AE-MeOH 25\% & $255-263$ & White crystal \\
AE-MeOH 30\% & $264-275$ & Nothing \\
AE-MeOH 35\% & $276-282$ & Nothing \\
\hline & $283-288$ & Nothing \\
& $289-293$ & Nothing \\
\hline
\end{tabular}

The flash and sephadex chromatography showed 2 pure components were isolated with $422 \mathrm{mg}$ of the shiny yellow crystals and $300 \mathrm{mg}$ of white crystals (table 4). Many fractions were expressed with the different elution solution, most especially with the EA/MeOH $10 \%$, EA/MeOH $20 \%$, $\mathrm{EA} / \mathrm{MeOH} 30 \%$.

Table 4. Flash chromatography.

\begin{tabular}{|c|c|c|c|}
\hline Elution solution & Fractions & TLC & Observations and results \\
\hline Hex/EA $20 \%$ & $\begin{array}{l}1-6 \\
7-15\end{array}$ & \multirow{4}{*}{$\begin{array}{l}\text { One strain } \\
\text { with flow } \\
\text { Flows } \\
\text { with one } \\
\text { strain } \\
\text { flow } \\
\text { flow }\end{array}$} & Fatty products \\
\hline Hex/EA $30 \%$ & $\begin{array}{l}16-20 \\
21-25\end{array}$ & & \multirow[t]{3}{*}{ Impure products } \\
\hline Hex/EA $40 \%$ & $26-35$ & & \\
\hline Hex/EA $50 \%$ & $36-40$ & & \\
\hline Pure EA & $41-50$ & Flow with & $\begin{array}{l}\text { Group of Fractions regrouped } \\
\text { for purification }\end{array}$ \\
\hline $\mathrm{EA} / \mathrm{MeOH} 10 \%$ & $51-54$ & 1 strain & $\begin{array}{l}\text { Group of Fractions regrouped } \\
\text { for purification } \mathrm{Wt}=2.9 \mathrm{~g}\end{array}$ \\
\hline $\mathrm{EA} / \mathrm{MeOH} 10 \%$ & $55-60$ & \multirow{3}{*}{$\begin{array}{l}1 \text { strain } \\
\text { and flows }\end{array}$} & Group of Fractions regrouped \\
\hline EA/MeOH $20 \%$ & $61-70$ & & for purification $\mathrm{Wt}=3.15 \mathrm{~g}$ \\
\hline EA/MeOH $30 \%$ & $71-80$ & & $\begin{array}{l}\text { Fractions regrouped for } \\
\text { purification } \mathrm{Wt}=0.97 \mathrm{~g}\end{array}$ \\
\hline EA/MeOH 50\% & $81-90$ & $\begin{array}{l}\text { Strain and } \\
\text { flow }\end{array}$ & $\begin{array}{l}\text { Group of Fractions regrouped } \\
\text { for purification }\end{array}$ \\
\hline $\mathrm{MeOH} 100 \%$ & $91-93$ & washing & $\begin{array}{l}\text { Group of Fractions regrouped } \\
\text { for } \mathrm{Wt}=0.84 \mathrm{~g}\end{array}$ \\
\hline
\end{tabular}

The first compound with $422 \mathrm{mg}$ with shiny yellow crystal was identified as glycosyl flavonoids the TLC demonstrated that it was a polar compound that showed a violet fluorescence at $365 \mathrm{~nm}$ UV figure 1. Other works of Nawel et al [16] and Lahouel [12] had used TLC for the identification of glycosyl flavonoids.

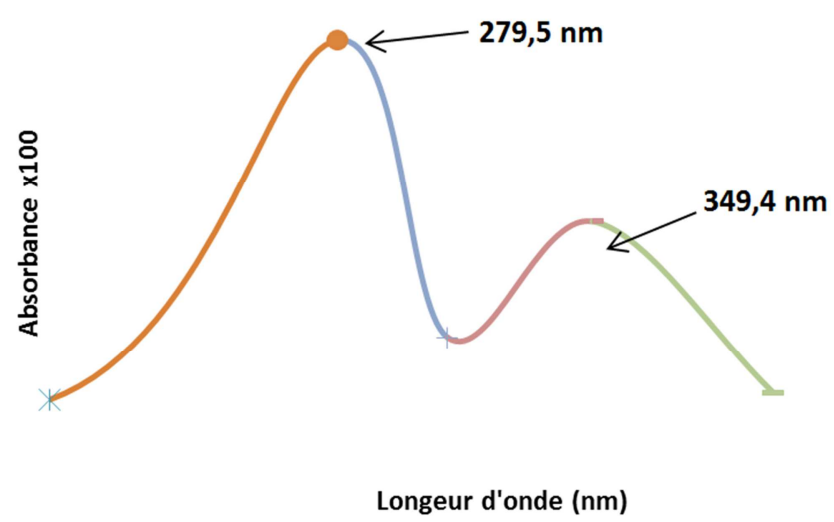

Figure 1. UV spectrum of the yellow crystal compound.

This compound was identified as a glycosyl flavonoid with substitution at the 3 position using IR, SM, RMN1H, ${ }^{13} \mathrm{C}$ and RMN 2D as shown in figure 2 .

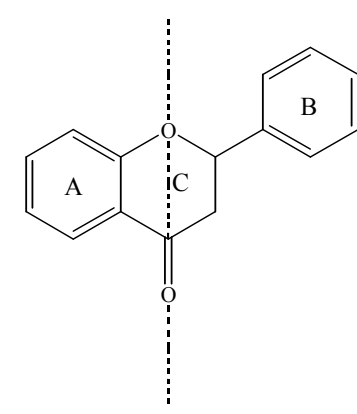<smiles>[R]c1c(-c2ccccc2)oc2ccccc2c1=O</smiles>

Figure 2. Glycosyl flavonoids isolated.

\subsection{Antibacterial Activity of Crude Extract of R. Heudoletti}

The results of the in vitro antibacterial activity of methanol extracts determined by diameters of inhibition zones are presented in Table 5.

Assessment of antibacterial activity was made by the disc diffusion method with $80 \mathrm{mg} / \mathrm{ml}$ concentration. Assay done on 12 bacteria strains. In vitro studies of the crude extract of R. heudoletti on most germs showed antibacterial inhibition diameter from $12 \mathrm{~mm}$ to $20 \mathrm{~mm}$. These results indicated that the diameters of inhibition zones varied from 12- $19.67 \mathrm{~mm}$ and $26-34.67 \mathrm{~mm}$ for the extracts and gentamycin respectively. Gentamycin used as a standard antibiotic at the concentration of $1 \mu \mathrm{g} / \mu \mathrm{l}$ exhibited higher diameters of inhibition than other extracts. No diameters of inhibition 
zones was obtained with dics containing pure methanol. Among the twelve isolates, eight bacteria (Staphylococcus aureus; Klebsiella pneumonia; Streptococcus feacalis; Escherichia coli; Pseudomonas aeruginosa; Morganella morganii; Citrobacter freundi; Enterobacter Cloacae) were sensitive to the extract. However, $P$. aeruginosa was the most sensitive with $19.67 \mathrm{~mm}$. S. typhi; K. oxytoca; S. flexneri; $P$. vulgaris; were the most resistant bacteria isolate with no diameters of inhibition zones. Studies conducted by Nawel et al [16] have shown that plant extracts with active phytochemical compounds like alkaloids, saponins and cardiac glycosides to be potent antibacterial and antimutagenic activities and Suh et al [18] also confirmed anticancer and antioxidant activities associated with alkaloids, coumarins and flavonoids.

Table 5. Antibacterial activities of $R$. heudolotti from the disc diffusion method.

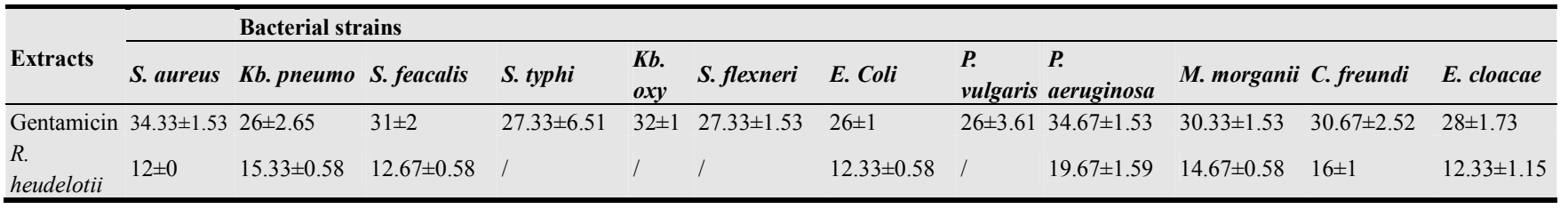

$\mathrm{S}$. aureus $=$ Staphylococcus aureus; Kb. pneumo =Klebsiella pneumonia; S. feacalis =Streptococcus feacalis; S. typhi =Salmonella typhi; Kb. oxy =Klebsiella oxytoca; S. flexneri = Shigella flexneri; E. coli =Escherichia coli; P. vulgaris $=$ Proteus vulgaris P. aeruginosa =Pseudomonas aeruginosa; M. morganii = Morganella morganii; C. freundi $=$ Citrobacter freundi; E. cloacae $=$ Enterobacter Cloacae;

The results of the antibacterial activity of the extract determined by Minimal Inhibitory Concentration (MIC) and Minimal Bactericide Concentration (MBC) are represented in Table 6. The MICs ranged between 188 and $750 \mu \mathrm{g} / \mathrm{ml}$ and The MBC ranged between 375 and $1500 \mu \mathrm{g} / \mathrm{ml}$. These results revealed that $P$. aeruginosa was the most sensitive with values of $188 \mu \mathrm{g} / \mathrm{ml}$ (Table 6). The MIC of the extract of $R$. heudelotii was less active than standard antibiotic (gentamycin) ranged between 5 and $10 \mu \mathrm{g} / \mathrm{ml}$. No result of MIC and MBC was determined for Salmonella typhi, Klebsiella oxytoca, Shigella flexneri, Proteus vulgaris isolates.

Table 6. MIC, MBC values $(\mu \mathrm{g} / \mathrm{ml})$ of $R$. heudolotti extract in the macro dilution assay comparable to gentamicin.

\begin{tabular}{|c|c|c|c|c|c|c|c|c|c|c|c|c|c|}
\hline \multirow{2}{*}{ Extract/gentamicin } & \multirow{2}{*}{ Parameters (ug/ml) } & \multicolumn{12}{|c|}{ Bacterial strains } \\
\hline & & SA & $\mathbf{K P}$ & $\mathbf{A B}$ & ST & KO & SF & EC & PV & PA & MM & $\mathbf{C F}$ & $\mathbf{E C}^{*}$ \\
\hline \multirow{3}{*}{ R. heudelotii } & MIC & 750 & 375 & 750 & 1 & / & 1 & 750 & / & 188 & 375 & 375 & 750 \\
\hline & $\mathrm{MBC}$ & 1500 & 750 & 1500 & l & l & l & 1500 & l & 375 & 750 & 750 & 1500 \\
\hline & $\mathrm{MBC} / \mathrm{MIC}$ & 2 & 2 & 2 & l & l & / & 2 & l & 2 & 2 & 2 & 2 \\
\hline \multirow{3}{*}{ Gentamicin } & $\mathrm{MIC}$ & 10 & 10 & 10 & 20 & 10 & 10 & 10 & 10 & 10 & 5 & 10 & 10 \\
\hline & $\mathrm{MBC}$ & 20 & 20 & 20 & 40 & 20 & 20 & 20 & 40 & 20 & 10 & 20 & 20 \\
\hline & $\mathrm{MBC} / \mathrm{MIC}$ & 2 & 2 & 2 & 2 & 2 & 2 & 2 & 2 & 2 & 2 & 2 & 2 \\
\hline
\end{tabular}

$\mathrm{S}$. aureus $=$ Staphylococcus aureus; Kb. pneumo =Klebsiella pneumonia; S. feacalis =Streptococcus feacalis; S. typhi =Salmonella typhi; Kb. oxy =Klebsiella oxytoca; S. flexneri = Shigella flexneri; E. coli =Escherichia coli; P. vulgaris =Proteus vulgaris P. aeruginosa $=$ Pseudomonas aeruginosa; M. morganii = Morganella morganii; C. freundi $=$ Citrobacter freundi; E. cloacae $=$ Enterobacter Cloacae;

The results of antibacterial activity of the fraction were determined in the table 6 . The fraction of methanol showed the best antibacterial activity than the fraction of acetone and methanol-ethyl acetate. The inhibitor diameter of the methanolic fraction varied from $12 \pm 0.6$ to $14 \pm 0.66$. The different fractions isolated given a good significant ratio MBC/MIC with values between 4 and 1. (Table 6).
Antimicrobial activity of fractions of the extracts of $R$ heudelotti from the disc diffusion method showed for methanol extract lowest diameter of $12 \pm 0.6$ for SA followed by 13 for $\mathrm{AB}$ (Table 7). Acetone extract showed the lowest diameter of 10 with respect to the methanol and methanol ethyl acetate.

Table 7. Antibacterial activity of fractions of the extracts of $R$. heudelotti from the disc diffusion method.

\begin{tabular}{|c|c|c|c|c|c|c|c|c|c|c|c|c|}
\hline Fxtract/Bac & SA & KB & AB & ST & KO & SF & EC & PV & PA & MM & CF & EC* \\
\hline Methanol (M) & $12 \pm 0.6$ & $14 \pm 0.3$ & $13 \pm 0$ & 1 & 1 & 1 & $13 \pm 0.33$ & 1 & $14 \pm 0.66$ & $14 \pm 0$ & $14 \pm 0$ & 0 \\
\hline Acetone (A) & $10 \pm 0$ & $11 \pm 0.66$ & $11 \pm 0$ & l & l & I & $11 \pm 0.7$ & l & $11 \pm 0.6$ & $12 \pm 0$ & $11 \pm 0$ & 0 \\
\hline Methanolethyl acetatel & $13 \pm 1.3$ & $13 \pm 0.66$ & $12 \pm 0.66$ & 1 & I & 1 & $12 \pm 0$ & 1 & $14 \pm 0.33$ & $12 \pm 1.7$ & $14 \pm 1.33$ & 0 \\
\hline
\end{tabular}

$\mathrm{SA}=$ Staphylococcus aureus; $\mathrm{KB}=\mathrm{Klebsiella}$ pneumonia; $\mathrm{AB}=\mathrm{Streptococcus}$ feacalis; $\mathrm{ST}=\mathrm{Salmonella}$ typhi; $\mathrm{KO}=\mathrm{Klebsiella}$ oxytoca; $\mathrm{SF}=\mathrm{Shigella}$ flexneri; $\mathrm{EC}=$ Escherichia coli; $\mathrm{PV}=$ Proteus vulgaris $\mathrm{PA}=$ Pseudomonas aeruginosa; $\mathrm{MM}=$ Morganella morganii; $\mathrm{CF}=\mathrm{Citrobacter}$ freundii; $\mathrm{EC}{ }^{*}=\mathrm{Enterobacter} \mathrm{Cloacae}$; $/=$ not determined

The MIC, MBC of $R$ heudolotti fraction in the micro dilution assay showed the lowest MIC of $6.25 \mathrm{ug} / \mathrm{ml}$ recorded on bacterial strain $\mathrm{KB}$ with the methanol and methanol ethyl acetate. Lowest MBC was recorded for the methanol ethyl acetate of 6.25 on the bacterial strain MM. The MBC/MIC ration was lowest for the methanol extract treatment for $\mathrm{AB}$ 
and MM, followed by SA and PA respectively.

Table 8. MIC, MBC values $(\mu \mathrm{g} / \mathrm{ml})$ of $R$. heudolotti fraction in the micro dilution assay.

\begin{tabular}{|c|c|c|c|c|c|c|c|c|c|c|c|c|c|}
\hline Fract/Bac & & SA & KB & $\mathbf{A B}$ & ST & KO & SF & EC & PV & $\mathbf{P A}$ & MM & CF & EC: \\
\hline \multirow{3}{*}{ methanol } & MIC & 12.5 & 6.25 & 12.5 & I & 1 & 1 & 6.25 & 1 & 12.5 & 12.5 & 1 & 1 \\
\hline & MBC & 25 & 25 & 25 & 1 & I & I & 25 & 1 & 25 & 12.5 & I & I \\
\hline & $\mathrm{MBC} / \mathrm{MIC}$ & 2 & 4 & 1 & I & I & I & 4 & I & 2 & 1 & I & I \\
\hline \multirow{3}{*}{ Acétone } & MIC & 12.5 & 12.5 & 12.5 & I & I & I & 12.5 & I & 12.5 & 12.5 & l & I \\
\hline & MBC & 50 & 50 & 50 & I & I & I & 50 & I & 50 & 50 & I & I \\
\hline & $\mathrm{MBC} / \mathrm{MIC}$ & 4 & 4 & 4 & I & 1 & I & 4 & I & 4 & 4 & 1 & I \\
\hline \multirow{3}{*}{$\begin{array}{l}\text { Methanol- } \\
\text { ethyl acetate }\end{array}$} & MIC & 25 & 6.25 & 12.5 & I & I & I & 12.5 & I & 12.5 & 12.5 & 1 & I \\
\hline & MBC & 100 & 25 & 50 & I & I & I & 50 & I & 25 & 6.25 & I & I \\
\hline & $\mathrm{MBC} / \mathrm{MIC}$ & 4 & 4 & 4 & 1 & 1 & 1 & 4 & 1 & 4 & 4 & 1 & 1 \\
\hline
\end{tabular}

$\mathrm{SA}=$ Staphylococcus aureus; $\mathrm{KB}=\mathrm{Klebsiella}$ pneumonia; $\mathrm{AB}=\mathrm{Streptococcus}$ feacalis; $\mathrm{ST}=$ Salmonella typhi; $\mathrm{KO}=\mathrm{Klebsiella}$ oxytoca; $\mathrm{SF}=\mathrm{Shigella}$ flexneri; $\mathrm{EC}=$ Escherichia coli; $\mathrm{PV}=$ Proteus vulgaris $\mathrm{PA}=$ Pseudomonas aeruginosa; $\mathrm{MM}=$ Morganella morganii; $\mathrm{CF}=$ Citrobacter freundii; $\mathrm{EC}^{*}=\mathrm{Enterobacter} \mathrm{Cloacae} ; /$ $=$ not determined

After purification two pure components were isolated the first named C22 with yellow shiny crystals and the second CJ with white shiny crystals. These compounds were tested and released a good anti bacterial activity with antibacterial inhibitor diameter between 11 to $15 \mathrm{~mm}$ for C22 and CJ from 13 to $14 \mathrm{~mm}$. (table 9). We noticed that when these two component are test both they produced an additional effect concerning antibacterial activity.

The antibacterial activity of the pure compounds isolated on the disc diffusion method table 9 showed the lowest records of 11 on strain SA and EC expressed by compound C22 treatment.

Table 9. Antibacterial activity of pure compounds isolated on the disc diffusion method.

\begin{tabular}{|c|c|c|c|c|c|c|c|c|c|c|c|c|}
\hline Fract/Bac & SA & KB & $\mathbf{A B}$ & ST & KO & SF & EC & PV & PA & MM & $\mathrm{CF}$ & EC* \\
\hline $\mathrm{C} 22$ & 11 & $13 \pm 0.33$ & $13 \pm 0.33$ & I & 1 & I & $12 \pm 0.66$ & I & $15 \pm 0.0$ & $14 \pm 0.6$ & I & 11 \\
\hline CJ & $13 \pm 0$ & $12 \pm 0.3$ & $13 \pm 0.3$ & I & I & I & $13 \pm 0.33$ & I & 14 & $13 \pm$ & $12 \pm 0.6$ & $13 \pm 0.3$ \\
\hline $\mathrm{C} 22+\mathrm{CJ}$ & $14 \pm 0.6$ & $14 \pm 0.33$ & 13 & I & I & I & $14 \pm 0.5$ & I & $14 \pm 0.25$ & $15 \pm 0.66$ & $15 \pm$ & $14 \pm 0.06$ \\
\hline
\end{tabular}

$\mathrm{SA}=$ Staphylococcus aureus; $\mathrm{KB}=\mathrm{Klebsiella}$ pneumonia; $\mathrm{AB}=$ Streptococcus feacalis; $\mathrm{ST}=\mathrm{Salmonella}$ typhi; $\mathrm{KO}=\mathrm{Klebsiella}$ oxytoca; $\mathrm{SF}=\mathrm{Shigella}$ flexneri; $\mathrm{EC}=$ Escherichia coli; $\mathrm{PV}=$ Proteus vulgaris $\mathrm{PA}=$ Pseudomonas aeruginosa; $\mathrm{MM}=$ Morganella morganii; $\mathrm{CF}=\mathrm{Citrobacter}$ freundii; $\mathrm{EC}{ }^{*}=\mathrm{Enterobacter} \mathrm{Cloacae}$; nd $=$ not determined

The MIC's and MBC results witnessed a best in vitro antibacterial activity of $R$. heudoletti (table 10) pure components isolated named $\mathrm{C} 22$ and $\mathrm{CJ}$ also demonstrated a very good ratio $\mathrm{MBC} / \mathrm{MIC}$. When these two components $\mathrm{C} 22$ and $\mathrm{CJ}$ tested both the results of ratio $\mathrm{MBC} / \mathrm{MIC}$ decreased, confirmation of the antibacterial synergetic affect (table 10). The study conducted by Eyoh et al, [9]; Ngoupayo et al, [17] showed that $\mathrm{MBC} / \mathrm{MIC}$ ratio less than 4 is an indication of bactericidal activity of a plant extract.

Table 10. MIC, MBC values $(\mu \mathrm{g} / \mathrm{ml})$ of $R$. heudolotti pure component in the micro dilution assay.

\begin{tabular}{|c|c|c|c|c|c|c|c|c|c|c|c|c|c|}
\hline Fract/Bac & & $\mathbf{S A}$ & KB & $\mathbf{A B}$ & ST & KO & SF & EC & PV & PA & MM & CF & EC* \\
\hline \multirow{3}{*}{$\mathrm{C} 22$} & MIC & 0.5 & 0.5 & 0.5 & 1 & 1 & 1 & 0.25 & 1 & 0.5 & 0.5 & 1 & 0.5 \\
\hline & $\mathrm{MBC}$ & 0.5 & 0.5 & 0.5 & l & I & l & 0.25 & l & 0.5 & 0.5 & / & 0.5 \\
\hline & $\mathrm{MBC} / \mathrm{MIC}$ & 1 & 1 & 1 & l & l & l & 1 & l & 1 & 1 & l & 1 \\
\hline \multirow{3}{*}{ CJ } & MIC & 0.25 & 0.5 & 0.5 & l & I & l & 0.25 & l & 0.5 & 0.25 & 0.25 & 0.5 \\
\hline & $\mathrm{MBC}$ & 0.25 & 0.5 & 0.5 & / & I & / & 0.25 & l & 0.5 & 0.25 & 0.25 & 0.5 \\
\hline & $\mathrm{MBC} / \mathrm{MIC}$ & 1 & 1 & 1 & l & l & l & 1 & l & 1 & 1 & 1 & 1 \\
\hline \multirow{2}{*}{ C22-CJ } & MIC & 0.12 & 0.25 & 0.12 & / & I & / & 0.25 & l & 0.11 & 0.12 & 0.12 & 0.12 \\
\hline & $\mathrm{MBC} / \mathrm{MIC}$ & 1 & 1 & 1 & l & I & l & 1 & l & 1 & 1 & 1 & 1 \\
\hline
\end{tabular}

C22: Yellow shiny crystals $(422 \mathrm{mg}$ ) identified and characterized as glycosyl flavonoid

CJ: White shiny crystals $(300 \mathrm{mg})$ not yet identified and characterized

\section{Conclusion}

At the end of this study we observed that the crude extract of R. heudoletti contained high levels of alkaloids, polyphenols, saponins and cardiac glycosides in both methanol and ethanolic extracts. The extract fractions and pure compounds showed promising antibacterial properties. The crude extract contains many phytochemical secondary metabolites. The chromatographic separation and elucidation of the crude extract from the fraction of methanol, acetone, and the fraction mixed methanol and ethyl acetate led to the selection of the fraction of methanol for purification. This fraction showed the best antibacterial activity.

Two pure compounds were isolated from the methanolic extract of $R$. heudeloti. The fist with yellow shiny crystal were characterized as iso-flavonoid, However further research needs to be carried out to identify the second pure 
molecule then a follow up study for safety by evaluating the sub-acute or chronic toxicities.

\section{References}

[1] Zaharia, V., Ignat, A., Ngameni *, B., Kuete, V., Moungang, L. M., Fokunang, N. C., Vasilescu, M., Palibroda, N., Cristea, C., Dumitrescu, L. S., Bonaventure T. Ngadjui, T. B. (2013): Heterocycles 23. Synthesis, Characterization and Anticancer activity of New Hydrazinoselenazole derivatives. Medicinal Chemistry Research Volume: 22 Issue: 12, 5670-5679.

[2] Ngameni Bathelemy, Ghislain W. Fotso, Justin Kamga, Pantaleon Ambassa, Tchoukoua Abdou, Aime' G. Fankam, Igor K. Voukeng, Bonaventure T. Ngadjui, Berhanu M. Abegaz and Victor Kuete, (2013), Chapitre 9: Flavonoids and Related Compounds from the Medicinal Plants of Africa. Edited by Victor Kuete, Elsevier, First edition.

[3] Awoussong, K. P., Zaharia, V., Ngameni, B., Kuete, V., Ntede, N. H., Abegaz, M. B., Ngadjui, T. B. (2014): Heterocycles 26. Synthesis, characterisation and anticancer activity of some thiazolic chalcones. Medicinal Chemistry Research, DOI: 10.1007/s00044-014-1096-8.

[4] Ngameni B, G. W. Fotso, E. Ngachussi, H. M. Poumale, B. T. Ngadjui, Yoshihito Shiono, and Tetsuya Murayama (2014): Hemisynthesis and Spectroscopic Characterization of Two Novel Allylated Benzophenones from Garcinia punctata Oliv. (Clusiaceae). Asian Journal of Chemistry; V ol. 26, No. 24, 0000-0000. No 17478 .

[5] Oyono VA 1, Fokunang CN, 1, Assam JP, Voundi S, Tsafack P, Tetwe EM, Ngadjui BT. 2014. Acute toxicity studies, antioxidant and in vitro antibacterial activities of extract from the barks of Ricinodendron heudoletti (Euphorbiaceae). Journal of Pharmacognosy and Phytotherapy Vol. 6 (4), pp. 47-53, DOI: $10.5897 / \mathrm{JPP} 2014.0312$, http://www.academicjournals.org/JPP.

[6] Momeni J, Djoulde RD, Akam MT, Kimbu SF. (2005). Chemical constituents and antibacterial activities of the stem bark extracts of Ricinodendron heudelotii (Euphorbiaceae). Indian J Pharm Sci. 67: 386-399.

[7] Noumi E. et Yomi A. (2001). Medicinal plants used for intestinal diseases in Mbalmayo Region, Central Province, Cameroon. Fitoterapia, 72: 246-254.

[8] Adjaouohan, J., Aboubakar, K., Ebot, E., Ekpere, J., Enow, G., Focho, D., Gbile, O., Kamanyi, A., KamsuKom, J., Mbeukeum, T., Mbi, N., Mbiele, L., Mbome, L., Mabiru, K., Nancy, L., Nkongmeneck, B., Satabie, B., Sofowara, A.,
Tanze, V., Wirmum, C., 1972. Traditionnal medecine and pharmacopoeia contribution to ethnobotanical and floristic studies in Cameroun. Trad. Med. Pharm. CST/OUA. P. 641.

[9] Eyoh. A., Michel Toukam. M., Gonsu. H., Fokunang. C., Atashili. J,. Lyonga. E., Ikomey. G., Mukwele. B., Mesembe. M., Tsague. N., Mandi. H., Okomo. A., (2013) Antibiotics Susceptibility Profile of Staphylococcus Aureus Isolated from the Anterior Nares of Hospital Personnel in Yaounde, Cameroon. Health Sci. Dis: Vol 14 (2). 17-25.

[10] Odebiyi. O and Sofowara. E. (1978). Phytochemical screening. Nigeria medical plants. Loydia 41: 231-234.

[11] Bruneton J. Pharmacognosie, Phytochimie et plantes médicinales. Edition Technique et Documentation-Lavoisier,

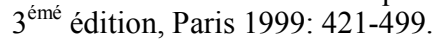

[12] Lahouel M., 2007. Interaction flavonoides-mithochondrie et rôle de la propolis dans la prévention de l'apopose induite dans certains médicaments anticancereaux: Thèse de Doctorat de l'Université de Mentouri de Constantine 220 p.

[13] Mangambu JDM, Kasali FM, Kadima JN. Contribution à l'étude phytochimique de quelques plantes médicinales antidiabétiques de la ville de Bukavu et ses environs (SudKivu, R. D. Congo). Journal of Applied Biosciences 2014; 75: $6211-6220$.

[14] Ngoupayo J, Mawouma NAR, Kwetché FPR, Matchawe C, Ngadjui TB. Phytochemical analysis and in vitro antimicrobial potential of the hydro alcoholic extract from the stem bark of Erythropleum guineensis: test on known resistance phenotypes-expressing strains. Int. J. Appl. Pharm. Biol. Chem. 2015; 4 (3): 719-728.

[15] Wagner H., Bladt S., 2001. Plant Drug Analysis. A Thin Layer Chromatography Atlas: Springer. New-York: 199-245.

[16] Nawel H., Ammar R. B., Afef W., Soumaya K., Amor M., Chibani J. B., Mariotte A. M., Ghedria K., Dijoux-Franca M. G., Ghedira L. C. (2005). Antibacterial and antimutagenic activity of extracts and essential oil from (Tunisia). Pistacia lentiscusToxicol Envir Chem, 87 (4): 567-573.

[17] Ngoupayo J, Ebene NMS, Kasali FM, Mpondo ME. Phytochemical screening and antibacterial properties from extract of Alchornea cordifolia (Schumach. \&Thonn.) Müll. Arg. Journal of Pharmacognosy and Phytochemistry 2015; 4 (3): 176-180.

[18] Suh N, Luyengi L, Fong HHS, Kinghorn AD, Pezzuto J. (1995). Discovery of natural product chemopreventive agents utilizing HL-60 cell differentiation as a model. Anticancer Res 15: 233-9. 